\title{
Accounting and fiscal impact of the micro and small companies of Huejutla of Reyes Hidalgo
}

\author{
Impacto contable y fiscal de las micro y pequeñas empresas de Huejutla de Reyes \\ Hidalgo
}

ROMERO-ESCUDERO, Carmina†, HERRERO-VÁZQUEZ, Laura Leticia, ESPINOSAHERNANDEZ, Abraham and RIVERA-MORALES, Claudia Eunice

Universidad Tecnológica de la Huasteca Hidalguense

ID $1^{\text {st }}$ Author: Carmina, Romero-Escudero / ORC ID: 0000-0001-8961-8656, CVU CONACYT ID: 344715

ID $1^{\text {st }}$ Coauthor: Laura Leticia, Herrero-Vázquez / ORC ID: 0000-0002-4891-0092, CVU CONACYT ID: 347168

ID $2^{\text {rd }}$ Coauthor: Abraham, Espinosa-Hernandez / ORC ID: 0000-0001-5044-4396, CVU CONACYT ID: 344739

ID $3^{\text {rd }}$ Coauthor: Claudia Eunice, Rivera-Morales / ORC ID: 0000-0003-3419-5187, CVU CONACYT ID: 347113

DOI: $10.35429 /$ JPE.2020.7.4.21.28

Received September 11, 2020; Accepted November 12, 2020

\begin{abstract}
The topic "Accounting and Fiscal Impact of Micro and Small Companies of Huejutla of Reyes, Hgo, was applied for its study to the food sales sector, the objective of this research is to understand the behavior of SMEs when using an accounting and fiscal regulation, for this research the mixed method was applied, for the qualitative part it was necessary to have a closer approach with the owners. and for the quantitative part, 314 surveys were applied with the support of 33 students. INEGI 2015 mentions that there are 394 food sales businesses, among the most outstanding data we find that of the 314 companies, 300 are micro-companies, that $74 \%$ of the people have not formalized their business, in relation to the IMSS 92\% do not has its company registered and $8 \%$ registered is equivalent to 69 workers, $75 \%$ express that they do not know that the deposits reflected in the financial system cause taxes, $85 \%$ do not invoice the general public. In general, the results show a profile of resistance to compliance with the provisions of art. 31 Section IV, of the Political Constitution of the United Mexican States.
\end{abstract}

SMEs, Awareness, Knowledge, Accounting-Tax

\begin{abstract}
Resumen
El tema "Impacto Contable y Fiscal de las Micro y Pequeñas empresas de Huejutla de Reyes, Hgo, enfocado al sector de la venta de alimentos, tiene como objetivo el estudiar el comportamiento de las pymes ante el uso de una normativa contable y fiscal, para esta investigación se aplicó el método mixto, se aplicaron 314 encuestas. Como dato sobresaliente encontramos que 300 de estas son microempresas, es decir la base de la economía la mueven las microempresas, y arrojaron lo siguiente, que el $74 \%$ de las personas no tiene formalizado su negocio, en relación al IMSS el $92 \%$ no tiene registrada a su empresa y el $8 \%$ registrado equivale a 69 trabajadores, el $75 \%$ expreso que no saben que los depósitos reflejados en el sistema financiero causan impuestos, el $85 \%$ no realiza facturas con el público general. De manera general los resultados muestran un perfil de resistencia al cumplimiento de lo dispuesto por el art. 31 Fracción IV, de la constitución Política de los Estados Unidos Mexicanos.
\end{abstract}

Pymes, Normativas, Economía

Citation: ROMERO-ESCUDERO, Carmina, HERRERO-VÁZQUEZ, Laura Leticia, ESPINOSA-HERNANDEZ, Abraham and RIVERA-MORALES, Claudia Eunice. Accounting and fiscal impact of the micro and small companies of Huejutla of Reyes Hidalgo. Journal-Public Economy. 2020- 4-7: 21-28

$\dagger$ Researcher contributing as first author 


\section{Introduction}

This work is focused on the study of two variables awareness and knowledge that the entrepreneurs of the micro and small companies of Huejutla de Reyes Hidalgo have, about the existence of an accounting and fiscal regulation, highlighting that the Micro and small companies (Mipe) have as It is challenging to face a globalized market, however the characteristics of these are of a lack of organizational structure and above all with a profile of resistance to change.

(Frankl, 2020, p. 42) mentions with his phrase: "When we cannot change the situation we face, the challenge is to change ourselves." Let's not forget that what is a challenge today, tomorrow will not be"

(Official Gazette of the Federation, February 28, 2013) "The criteria for classifying companies in Mexico are determined based on the number of workers employed in them and by sector".

\begin{tabular}{|l|r|r|r|}
\hline \multicolumn{1}{|c|}{ Size } & \multicolumn{3}{c|}{ Sector } \\
\hline Micro & Industry & \multicolumn{1}{c|}{ Commerce } & \multicolumn{1}{c|}{ Services } \\
\hline Little & $11-50$ & $0-10$ & $0-10$ \\
\hline Median & $51-250$ & $11-30$ & $11-50$ \\
\hline Big & 251 onwards & 101 onwards & 101 onwards \\
\hline
\end{tabular}

Table 1 Classification of companies in Mexico by number of employees

Source: (INEGI, 2005)

The mype in Mexico, constituted 99.7\% of the total of companies, and generators of employment of $79 \%$ of the population, and generate income equivalent to $23 \%$ of the Gross Domestic Product (GDP), the above is a clear sign that You should pay attention to these types of companies and see them as what in reality are the basis of the Mexican economy.

INEGI, (2006, p. 12), According to the latest Economic Census published by the National Institute of Statistics and Geography (INEGI), of the universe of economic units in Mexico: a) $95.2 \%$ are microenterprises, b) they generate $45.6 \%$ of employment, and c) contribute $15 \%$ of the added value of the economy.
Ruiz, (2010, p. 12), Secretary of the Economy in Mexico. The mype represent for the nation $99.8 \%$ of the $4 ' 007,100$ economic units, $52 \%$ of Gross Domestic Product and $72 \%$ of formal jobs, and are a potential for the sustainable and sustainable development of the nation.

I emphasize that this research was focused on MSM companies, that is, micro and small companies are included, of which the results showed that 893 jobs were generated out of 314 food businesses, but an important data is that 300 are micro companies and 4 are small businesses, this indicates that the market in Huejutla, as in the rest of the country, is driven by micro-businesses, taking into account that there are levels of micro-businesses, including simple taco stands, small inns, lunch boxes, sale of tamales, atole, cakes, corner businesses, restaurants, rotisseries, pizzerias, the famous cheap dining rooms, the business selling Zacahuil, and let's add the infinity of informal businesses selling cakes, basket enchiladas, those who ride their bicycle carts selling the atoles and tamales etc., these formal and informal micro-enterprises are identified by their limitations, an example is that many of them do not even c They have a name as part of their corporate image. But even so, these are the ones that really move the economy, they generate at least one job and in most cases the owner also performs several functions, since they do not have the resources or the conditions to establish a division of labor, as do the big enterprises.

The micro-enterprises in the interviews show that they are reluctant to implement organizational changes, they prefer to inject their few resources into the raw material that gives movement to the business, which gives employment to family members, it was also obtained that our authorities must to take as a reference the promotion of strategies, including injecting them capital under an accompaniment to strengthen them, considering that they are the basis of our economy. 
Micro-enterprises are a niche to flourish, there is much to do for them, that is, to strengthen the advantages such as having a closeness with clients, having an entrepreneurial attitude, a fighting spirit, because they know that a financial system will not be waiting for them to grant a credit at low rates, they know that they have to keep up with the competition, which is their greatest impulse, that their advertising is done by themselves in their dealings with customers, on the other hand there are their weaknesses, not having the enough resources for its development and to face a globalized market, for this the government is currently giving the support that allows a more competitive, freer market and this gives us the growth of the gross domestic product.

In Mexico as of June 30, 2009, the size is determined based on the total number of staff in the organization and the level of annual sales, leaving up to 10 workers for micro-enterprises and with an annual sales amount of up to four millions of pesos.

Secretary of Economy, (2010, p. 12) The Secretary of Economy trusts that it is a tool for the mypes to take advantage of the federal or state development programs adequately, avoiding granting these benefits to companies that, although due to their minimum number of workers is small, but due to its billing level of millions of pesos, it is considered large. This new classification is intended to avoid considering them as micro, small or mediumsized companies.

This study showed that within the administrative weaknesses is the resistance to the application of accounting and fiscal regulations, even though the authority has always existed a legality that obliges the owners of micro-enterprises to contribute to public spending. Article 31 Fraction IV of the constitution "contribute to public spending in a proportional and equitable manner" On the other hand there are also contributions from economists such as Adam Smith who reinforced the constitutional mandates through his theoretical tax principles in the 18th century and that still have after -cendency mentioning the principle of justice, certainty, comfort and economy, interpreting that the contribution must be easy to digest, that is, timely, proportional, without exceeding their economic capacities.

\section{Objective}

Study the behavior of the mypes of Huejutla de Reyes, of the food turnover; due to their awareness and knowledge to comply with accounting and tax obligations.

\section{Method and Instrument}

The instrument used to collect the data was a survey structured by 26 items with multiple choice answers, the questions were classified into the following sections: Module I., covers the general data of business owners, Module II, referring to consciousness made up of 6 items, Module III, covers fiscal knowledge with 17 items, Module IV, accounting knowledge with 3 items.

As a means of verifying the application of the survey, photos were taken that evidenced the visit to the companies, the information was reinforced with the interview with 10 entrepreneurs, this mixed technique allowed to visualize the characteristics of the food sales businesses, such as size, infrastructure, appearance, reactions, and feelings of the owners, etc.

\section{Sampling and sample size}

For this study the target population were the companies located in the municipality of Huejutla de Reyes Hidalgo, which according to the Municipal Development Plan 2016-2020 is made up of 6 subregions: 1.Huejutla municipal head, 2.- Teacal 3.-Chililico , 4.-Coacuilco, 5.Tehuetlan, 6.- Chalahuiyapa and these in turn are made up of 187 towns. According to (INEGI 2015) there are 394 companies in the food sector, of which the survey was applied to 314 , according to the formula to calculate the sample size of finite populations, a confidence level of 95\% was obtained, For the collection of information, 33 students were trained to apply the instrument with the freedom to choose the business, each one was responsible for capturing the results to an online digital platform, later the capture and evidence of the surveys was reviewed to support that they meet the reliability requirements. 


\section{Scope}

Hernández Fernández \& Baptista, (2010), This study was through the mixed method, for the qualitative part, the experiences of the entrepreneurs are taken into account, the photographs taken, these complement the quantitative data that the application of the survey.

\section{Analysis of the information}

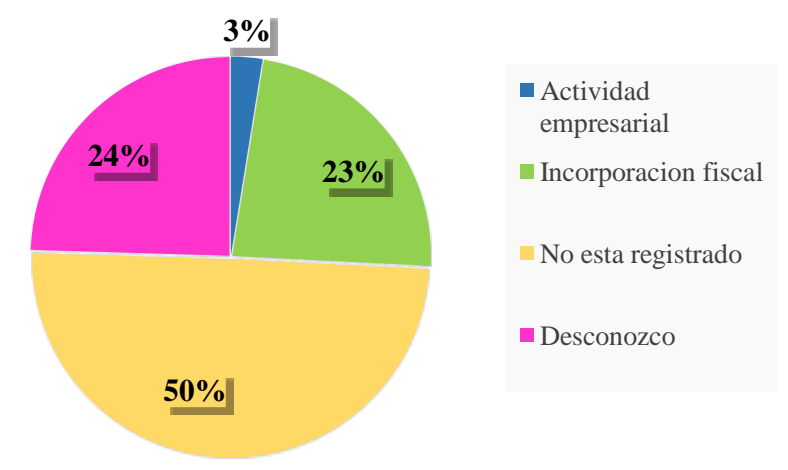

Graphic 1 How do SMEs in the food sector participate in public spending?

Source: Own Elaboration

Twenty-three percent of the companies are registered in the tax incorporation regime (RIF), 3\% are registered in the business activity regime, $50 \%$ are not registered in any regime and $24 \%$ do not know that they must be registered in a regime, This GRAPHIC states that of 313 companies surveyed, only $26 \%$ are complying with the payment of taxes, and $74 \%$ do not participate.

Giannatale, Ramirez, Smit (2008), Formal companies will have an annual net profit that is $18 \%$ lower than they currently obtain in the informal sector, despite their larger size, they choose to triple their investment in capital and increase the number of workers by $24 \%$ and thus be able to face costs and fiscal responsibilities. Informal companies would not be able to obtain greater benefits than they currently obtain operating as informal. Extracted The RIF was born as a result of the tax reform for 2014, and its objective was to combat informality, it captures taxpayers who in the annual period do not exceed \$2'000,000.00 and the purpose of the scheme is to allow them to comply easily with its tax obligations, which would in turn bring access to social security services, create an entry point for businesses to formality, both in the fiscal and social security fields.
Before this reform, there was the small taxpayer regime (REPECOS) which consisted of paying a fee such as ISR and VAT tax, did not consider the IEPS, and only consisted of looking for the corresponding income range and from there it was determined the quota, and they went to pay, this regime was eliminated because it did not include in its rules supporting operations with invoices, purchases and income were exempt from invoicing, an act that broke the chain of fiscal verification, which generated spaces for evasion and tax avoidance that were taken advantage of by some taxpayers who unduly pay taxes under this regime.

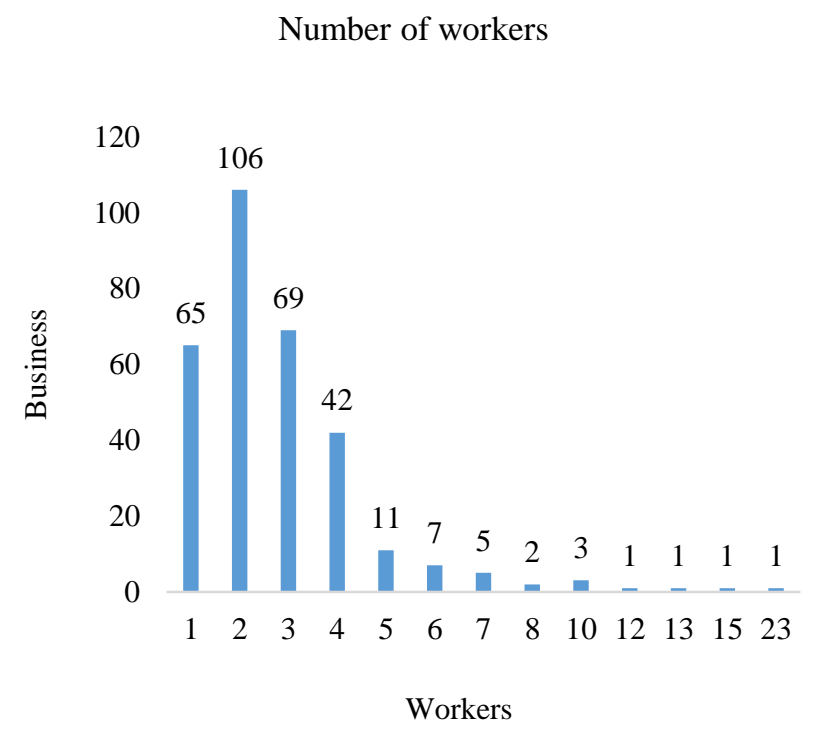

Graphic 2 Types of companies based on the number of workers

Source: Own Elaboration

\begin{tabular}{|r|r|r|}
\hline $\begin{array}{c}\text { Number of companies } \\
\text { surveyed }\end{array}$ & $\begin{array}{c}\text { Number of } \\
\text { workers per } \\
\text { company }\end{array}$ & $\begin{array}{c}\text { Workers } \\
\text { Employees }\end{array}$ \\
\hline 65 & 1 & 65 \\
\hline 106 & 2 & 212 \\
\hline 69 & 3 & 207 \\
\hline 42 & 4 & 168 \\
\hline 11 & 5 & 55 \\
\hline 7 & 6 & 42 \\
\hline 5 & 7 & 35 \\
\hline 2 & 8 & 16 \\
\hline 3 & 10 & 30 \\
\hline 1 & 12 & 12 \\
\hline 1 & 13 & 13 \\
\hline 1 & 15 & 15 \\
\hline 1 & 23 & 23 \\
\hline
\end{tabular}

Table 2 Types of companies based on the number of workers

Source: Own Elaboration 
We can see that of the 314 companies focused on the food sector, there are 893 jobs, 4 are small companies and 300 are micro companies. This result shows that microenterprises are the ones that really move the economy, and those that are generating at least one job.

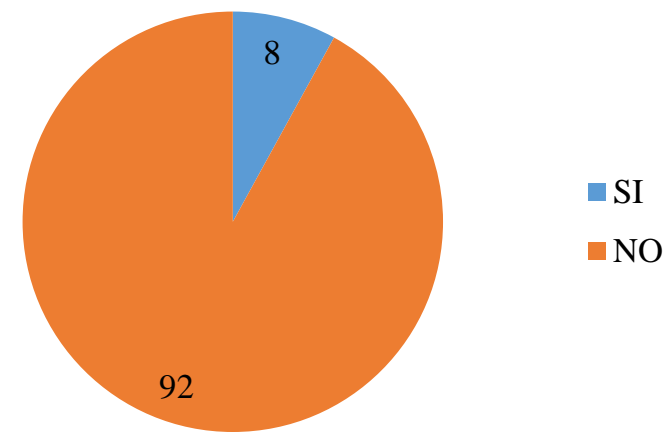

Graphic 3 Workers have social security benefits Source: Own Elaboration

Eight percent of the companies are registered with the Mexican Institute of Social Security (IMSS), and 92\% are not registered. 8\% active corresponds to 69 companies and ninetytwo percent corresponds to 824 companies.

The 1917 Constitution includes the commitment to guarantee and apply preventive health measures, which is why Mexico is a pioneer in social security matters, and it was until 1943 when the Social Security Law was promulgated, during the Cardenista administration. With this Law, the Mexican Institute of Social Security was created, which becomes the most important institution in matters of health and social security, which had the following benefits: occupational accidents and diseases; non-occupational diseases and maternity; disability, old age and death, as well as involuntary unemployment in advanced age.

The interest in protecting the working class, we can see that it has been a priority, however our results show that for the microenterprises of Huejutla de Reyes Hidalgo it is not the most important.

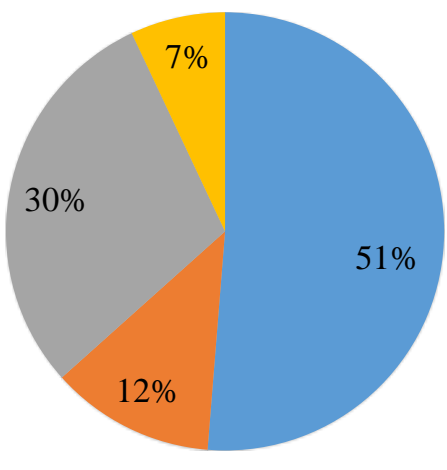

$\square$ Totalmente $\square$ Medianamente $\square$ Desconoce $\square$ Vagamente

Graphic 4 Are you aware that if you do not comply with the payment of taxes, the authority can generate sanctions? Source: Own Elaboration

Fifty-one percent of the companies mention being aware, $12 \%$ moderately, 30\% unknown and $7 \%$ vaguely that if they do not comply with the payment of taxes, they can obtain sanctions from the authority.

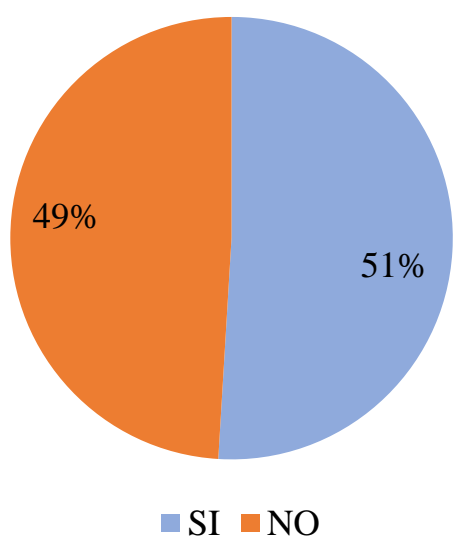

Graphic 5 They know that they must support operations with vouchers (invoices for purchases, sales, investments, expenses)

Source: Own Elaboration

Fifty-one percent of the companies mention being aware, $49 \%$ are not aware, that they must support operations with tax receipts.

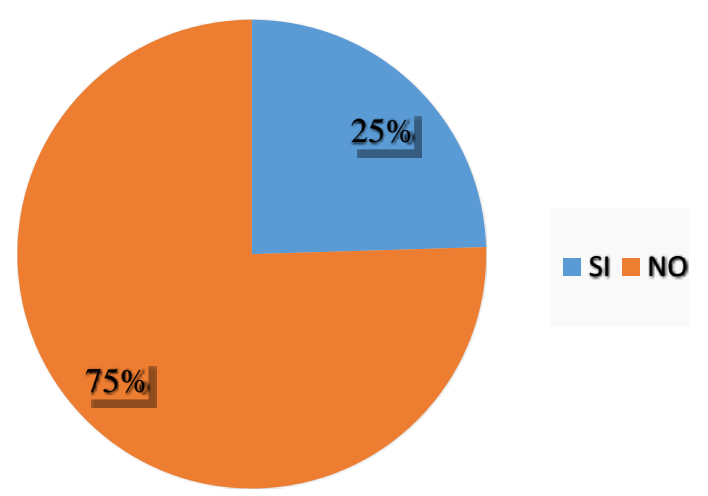

Graphic 6 The deposits that appear in the bank statement are part of your income that you must declare before S.H.C.P

Source: Own Elaboration

ROMERO-ESCUDERO, Carmina, HERRERO-VÁZQUEZ, Laura Leticia, ESPINOSA-HERNANDEZ, Abraham and RIVERAMORALES, Claudia Eunice. Accounting and fiscal impact of the micro and small companies of Huejutla of Reyes Hidalgo. Journal-Public Economy. 2020 
$25 \%$ know that the bank statement deposits are part of their income that must be declared and $75 \%$ do not know.

Article 41 of the Federal Tax Code (CFF) informs us that if taxpayers, regardless of their size, do not pay their taxes, do not issue invoices, do not support their operations with tax receipts, evade the income that is reflected in the account statements, etc. they are entitled to sanctions by the authority, however the results obtained in graphs 4,5,6 reflects that the authority based on art. 33 of the CFF, "obligations it has with taxpayers", it can be seen that it needs to work more to improve the results of the study variables, which is the knowledge and awareness of taxpayers in this case to micro-enterprises and if necessary to establish accompaniment strategies.

\section{Article 33 of the Federal Tax Code}

- $\quad$ Free assistance to taxpayers to explain tax provisions, in plain language, away from technicalities, if deemed necessary with brochures.

- Maintain offices in various parts of the national territory to guide taxpayers.

- $\quad$ Establish trustees to represent taxpayers

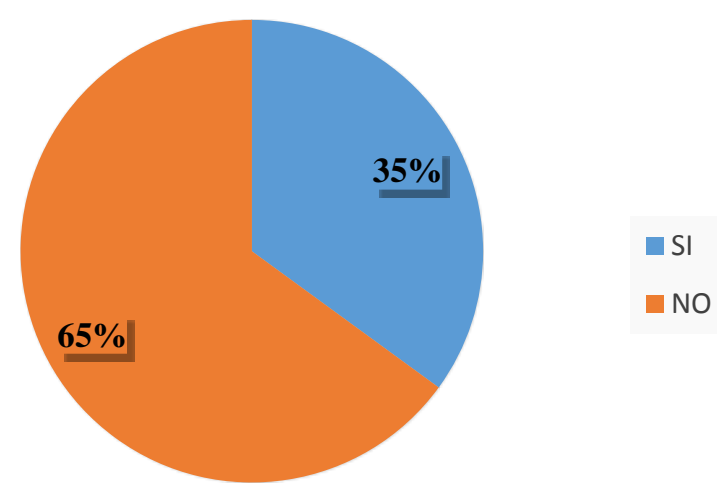

Graphic 7 Does your company use banking point of sale terminals to strengthen sales?

Source: Own Elaboration

Sixty-five percent of companies do not use bank POS terminals, while only $35 \%$ of companies do.
As part of a collection project and to give taxpayers billing facilities, the SAT and the Association of Banks of Mexico, implemented a new way of billing for when payments are made with credit or debit cards to which the Banks will add the federal taxpayer registry to the chip of the credit card and this will issue the $\mathrm{xml}$ of the invoice and it will be available on the platform of the tax administration system When the immediate invoice mechanism is used and the taxpayer declares amounts of income lower than those deposited to cover the debit of these cards, we will be in a fiscal discrepancy table based on article 91 of the Income Tax Law.

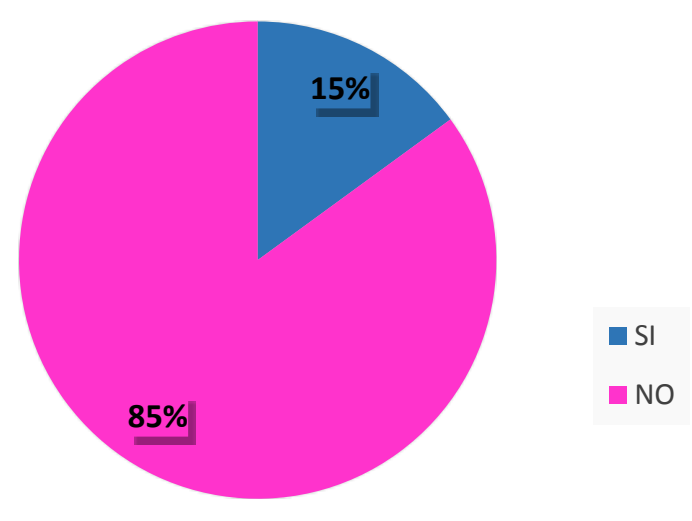

Graphic 8 Do you generate invoices for the amounts of sales to the general public?

Source: Own Elaboration

Fifteen percent of the companies did generate invoices for the amounts of sales to the general public and $85 \%$ of the companies answered that they did not. Food microbusinesses state that they issue invoices only if the customer requests them, otherwise this generates a higher tax, and affects their profits.

It is alarming to see the handling of these bad practices since if the authority discovers them it can make use of its faculties, however in the case of the sale of food the indirect VAT tax is $8 \%$, for the general public when it reaches the amount of $\$ 300,000.00$ per year, and this is an added cost that the customer will have to pay for each diner that is why, in order not to affect sales by raising the price, they prefer not to issue invoices. 


\section{Conclusions}

This study was carried out in Huejutla de Reyes Hidalgo under the mixed method, aimed at companies in the food sector, the results show little participation in compliance with accounting and tax regulations, due to the lack of awareness and knowledge, that the executives, for this study 314 surveys were applied, which yielded an important data that 300 are microcompanies and 4 are small companies, this indicates that the food trade in Huejutla de Reyes Hidalgo is under the control of microcompanies, to which we would have to take care and work together with the authorities, chambers of commerce, educational institutions, which we have the responsibility of encouraging them to change their organizational structures, to promote an accounting and tax culture, through strategies such as the economic support that is being granted, but with a follow-up that helps them capitalize on their assets.

Based on data from INEGI 2015, three hundred and ninety-four food sales businesses are registered, of which $74 \%$ have not formalized their business before the Ministry of Finance and Credit (SHCP), and of that $74 \%$ only $8 \%$ have their workers registered with the IMSS, that is, only 69 workers have social security. As part of the work we have for this sector of micro-enterprises is to work together educational institutions, authorities, chambers of commerce, etc., to generate the implementation of projects focused on the administrative part, such as the management of simple accounting, which Without so much obstacle they can make the payment of taxes in an uncomplicated way, nor with so much cumbersome procedure that scares them and that makes them resist compliance with accounting and tax regulations.

The tax collecting authorities must make an analysis of the microenterprise scenario, since we can see that there is little participation in the payment of taxes and management of accounting, for this it is retaken that if for small and large companies the The situation of applying accounting and tax regulations, even more so for micro-enterprises that are struggling to survive, to keep up with their competition, that is, if the authority expects the participation of the tax, they should start by analyzing the forms of collection to give them a different treatment, appropriate to their possibilities.
Taking into account that there are levels of buses, and there are cases where it is preferable that there is an adaptation between the active and passive subject, allowing them to enter the game, to stay on the bench as mere spectators and they do not want to migrate to be part of formal trade. The replacement of the REPECO regime by the fiscal incorporation regime as a measure to improve tax collection as of 2014, was attractive due to the proposal of the existence of a fiscal stimulus for the benefit of taxpayers, however I consider that it should not have been $100 \%$ eliminated REPECO, because if the decision made by the authority to eliminate it was to prevent taxpayers from continuing to evade the exemption of invoices that was allowed in that regime, that was only a matter of complementing. Within REPECO, payment was also facilitated by seeking a fixed fee according to their sales, it is something that Microenterprise taxpayers were motivated to pay, it was facilitated and that is an aspect that the authority should not lose sight of. if you want to achieve the maximum collection.

Another way to improve collection, and comply with art. 31 Fraction IV of the Political Constitution of the United Mexican States, (CPEUM) is to make another classification based on the type of income of microenterprises, which could enjoy a tax scheme similar to REPECO, that is, that applies to businesses that effectively remain in a struggle for survival, it is clear to us that not all micro-enterprises are at the top of annual income of $\$ 4,000,000.00$

In relation to the banking system, seventy-five percent express that they do not know that the deposits reflected in the financial system cause taxes, here the law is very demanding, we cannot generalize to microenterprises, not all of them can have knowledge of this concept, if some They do not have the financial resources to divert them to have a bank account where they deposit their sales. In the interviews, the entrepreneurs commented that the banks agree with the SHCP and that they better not get into trouble.

Thirty-five percent of the companies use the banking point of sale terminal tool, while only $65 \%$ of the companies do not use it, remember that the income that is captured through this means is not possible evade them, they would automatically have to enter the taxable base. 
Another result was that $85 \%$ do not invoice the sales of the general public, these are consumers who are not registered in the SAT, and who do not require the invoice, for this graphic the owners expressed that they have clients that do require a invoice to verify their food expenses either because they work in government agencies or private companies and it serves to verify the expense or to deduct it in their company, in these cases if they issue the invoice but the client is told that they will add to their cost VAT, being an erroneous action, since VAT must be included in the cost. The complicated thing about the $85 \%$ that does not bill the general public is that there is a very clear evasion of income tax, likewise, when food businesses exceed $\$ 300,000.00$ per year they have to pay VAT for sales to the general public and the rate is Very high, for the food sector $8 \%$ is established, therefore in these cases they prefer not to invoice so as not to increase the price to customers, because it is observed that the value added tax is not included in their costs. These bad practices are carried out by a lack of knowledge and above all lack of awareness.

I would also like to leave this section as a reflection for the authority that I consider also has the responsibility to carry out these actions, as it is possible that by making use of tax secrecy, large companies are waived taxes and in the case of micro-companies that struggle to survive, they are not given a treatment proportional to their characteristics, because on the one hand they are considered microbusinesses up to $\$ 4,000,000.00$ per year, but on the other hand the law tells us that after $\$$ $300,000.00$ of income from public sales in In general, they are affected with a percentage of $8 \%$ of VAT, for the food sector, a percentage that affects the cost of each diner, and that is why they prefer not to declare it. Environmental conditions do not affect companies of different sizes in a uniform way. On the contrary, in general terms, small companies suffer more from environmental obstacles than large ones (World Bank, 1997; Brunetti et al., 1998; Schiffer and Weder, 2001). Specifically, smaller companies report having more problems than larger ones in terms of financing, taxes and regulations, inflation, corruption, crime and anticompetitive practices. However, there do not seem to be differences in the impact of the availability of infrastructure, political stability or the functioning of justice on companies of different sizes.

\section{References}

Centro de Estudios Sociales y de Opinión Pública, "Antecedentes", en Seguridad Social [Actualización: 17 de febrero de 2006], en www.diputados.gob.mx/cesop/Centro de Estudios Sociales y de Opinión Pública, "Antecedentes", en Seguridad Social 17 febrero 2003), http://archivos.diputados.gob.mx/Centro s_Estudio/Cesop/Comisiones/2_ssocial.htm\#: : text=En\%20el\%20pa\%C3\%ADs\%2C\%20los\% 20antecedentes,empresarios $\% 20 \mathrm{de} \% 20$ atender $\% 20 a \% 20$ sus

Cámara de Diputados del H. Congreso de la Unión. (2020, 8 de diciembre)Ley del impuesto al valor agregdo.http://www.diputados.gob.mx/LeyesBi blio/pdf_mov/Ley_del_Impuesto_al_Valor_Agr egado.pdf

Cámara de Diputados del H. Congreso de la Unión. (2020, 8 de diciembre) Ley del Impuesto Sobre la renta. http://www.diputados.gob.mx/LeyesBiblio/pdf/ LISR_091219.pdf

Cámara de Diputados del H. Congreso de la Unión. (2020, 18 de diciembre) Constitución Política de los Estados Unidos Mexicanos.http://www.diputados.gob.mx/Leyes Biblio/ref/cpeum.htm

Cámara de Diputados del H. Congreso de la Unión. (2020, 21 de octubre) Ley del Seguro Social.

http://www.imss.gob.mx/sites/all/statics/pdf/ley es/LSS.pdf

Cámara de Diputados del H. Congreso de la Unión. (2019, 9 de diciembre) Código Fiscal de la Federación. http://www.diputados.gob.mx/LeyesBiblio/pdf/ 8_090120.pdf

Louis, Luis F , Jorge H (2011). En a. D. Pymes, Emprender, Dirigir y Desarrollar Empresas. Mexico: Mexicana.

Nuño, P., (2012) Administración de Pequeñas Empresas. Recuperado de http://aliat.org.mx/BibliotecasDigitales/econom ico_administrativo/Administracion_de_pequena s_empresas.pdf 